\title{
Introduction: Othering Race and Ethnicity in Media and Popular Culture
}

\author{
GUEST EDITOR: DR. RUTH SANZ SABIDO, Canterbury Christ Church University
}

Numerous scholarly analyses have examined the representations of race and ethnicity in the Western media (Hall 1997; Macdonald 2011; Poole 2002; Poole and Richardson 2006). Most of these studies draw our attention to how the 'inferior' Other is depicted by 'superior' Western agents, and to the imbalances of power that underpin those portrayals. For instance, according to Hall (1997), the use of binary opposites such as 'good' and 'evil', or 'civilised' and 'uncivilised', has its roots in (post)colonial relations of power. In a similar vein, Said (1978) states that the inclusion of certain cultural forms, and the exclusion of others, is explained by the orientalist notion that European identity is superior to all non-European cultures, which are presented as backward and dependent. The postcolonial background to these practices, however, is usually only implicit in media analyses, rather than explicitly developed as the framework within which these representations are produced (Sanz Sabido 2013).

In addition, most academic work in Postcolonial Studies has focused on literary works, while overlooking media representations and, more broadly, media production. Yet, if we consider the fact that postcolonialism involves 'a whole theoretical or ideological agenda' which is 'far from historically or politically innocent' (Eagleton 1998, 125), then media outputs provide suitable material for the analysis of the postcolonial agenda. In this respect, Brunt and Cere (2011) argue that Britain's role as the colonial 'centre' is strongly intertwined with British contemporary media cultures, so media production in Britain must be analysed by taking into account the postcolonial power structures that continue to shape it.

This special issue is concerned with the analysis of representations which are underpinned by postcolonial relations of power. Through the analysis of films, television programmes, news articles, magazines and murals, the following papers explore the connections between contemporary cultural and media outputs and postcolonial legacies. However, media and cultural contexts are not solely defined by postcolonialism, but also by commercial imperatives that are primarily concerned with what can be sold, read and/or viewed the most. The postcolonial, therefore, cannot be viewed separately from commercial forms of communication, or from capitalism and the patriarchal order, which also determine (and are constituted by) unequal power relations between gendered subjects.

Pawling (2011) makes this point forcibly when he argues that the mass media play a vital role in the dissemination of Western versions of freedom and democracy, as well as in the formation of the human subject itself. Referring to major media organisations, such as Rupert Murdoch's News Corporation, Pawling states that 'an Anglo-American version of political reality is presented as the only "rational" basis for interpretation and action' $(2011,143)$. This version of reality is inherently orientalist and, consequently, Postcolonial Studies should not only be concerned with the study of literary works, but also with the media.

The postcolonial 'ideological agenda' and 'lack of innocence', to use Eagleton's expressions, must therefore be understood as the maintenance of financial channels of domination (through the control of key economic resources) and through military interventions. Referring particularly to the 'war on terror', Krishna (2009) points out that recent conflicts which have 
sought to foment a 'narrow notion of patriotism and cement existing hierarchies in the world order' (163) should also be considered in terms of the postcolonial. More specifically, he argues that the 'war on terror' is fundamentally an orientalist conflict, as it is based on the principle that some nation-states are still eager to promote their superiority over 'the Rest', represented in this particular case by the Islamic 'threat' (172). In this respect, 'colonialism is not just political imposition and economic exploitation but a form of violent planetary consciousness that afflicts us all collectively' (172).

The analysis of media representations of race and ethnicity, and the multiple perspectives from which these studies can be approached, has created, therefore, a vibrant field of scholarly research. This was confirmed by the overwhelming response to this edition's call for papers. The articles in this collection also engage closely with understandings of the past, either by the explicit or implicit use of a (post)colonial framework, or through other methodological and theoretical formulations. The result is a collection of papers which, based on doctoral research by $\mathrm{PhD}$ candidates and recent $\mathrm{PhD}$ graduates, contribute original knowledge to the field.

The first two articles deal with practices of classification which are a product of, and are characterised by, the postcolonial relations described above. In 'Italian-Americans' contested whiteness in early cinematic melodrama', Valerio Coladonato explores the use of categorisations to distinguish between different racial 'types' in American melodramatic representations of Italian-Americans. Coladonato discusses how, in order to accommodate the need of cheap immigrant labour while maintaining the purity of the 'white' (e.g. AngloAmerican) core of society, Italian-Americans were only provided with 'probationary whiteness' and were deemed as racially inferior. In his article 'Racialised body modifications: framing genital mutilation, cosmetic surgery and gender assignment surgery', Mathis Danelzik also pays attention to the inconsistencies that exist in the linguistic categorisation of different practices of genital modifications, which may be described as 'mutilation' or as 'cosmetic surgery' depending on their racial framing and the degree of rationality that is assumed in each case. Danelzik focuses particularly on Western representations of female genital modifications in Western and African contexts. In the following article, 'Othering Racialised Femininity in Hip-Hop Journalism', Barbara Anna Panuzzo also draws upon the postcolonial representation of women, examining the ways in which the editorial agendas of the hip-hop press produce gender and race-specific discourses of the 'Other' (in this case, female hip-hop artists). Panuzzo argues that articulations of identity in hip-hop journalism are rooted in the fetishisation of the Black female body.

Representing interdisciplinary approaches to the analysis of media and ethnicity in media and popular culture, Laura Aguiar and Stephen Bennett draw upon the concept of 'collective memory' in postcolonial contexts. First, Laura Aguiar's article "'Look what we have gone through": representation and memory in the Bogside murals in Northern Ireland' examines how The People's Gallery in Derry 'remember' the Troubles, what stories are included or excluded, how 'Us' and 'Them' are portrayed, and how the depiction of the past relates to the present. In 'The Othering of Palestinians in film: Munich (2006) and Waltz with Bashir (2009)', Stephen Bennett combines the concept of 'collective memory' with elements of critical race theory, in order to examine the problematic aspects of modern film representations of Arabs in the Arab-Israeli conflict. Bennett points out how film provides a popular medium through which Palestinians are actively Othered, sometimes even in films that have set out to upend dominant narratives. 
The final two articles provide alternative analyses of representations of the Other. While most recent studies of representations of Muslims take into account the attacks of September 11 and July 7, Matt Atkinson's article, 'Binary representations: British press reporting of the Muslim/Asian Other outside the context of terrorism (1989-2007)', explores the ways in which the coverage of the Muslim Other has changed over time by examining three case studies (the Satanic Verses incident of 1989, the Bradford Riots of 2001, and the Gillian Gibbons incident of 2007). Atkinson's findings suggest that the representation of Muslims may, in fact, have become more positive at some points between 1989 and 2007, although the need to reconcile the terrorist Other with Britain's multiculturalism has led to a duality in the British coverage of Muslims, meaning that Muslims can only ever be 'good' or 'bad'. The special issue concludes with Michael Ahmed's “"Who is Sir Curtis Seretse?": A re-evaluation of black representation in sixties British television'. Ahmed re-evaluates the significance of Sir Curtis Seretse, a black character from the 1960s television series Department $S$ (ITV, 1969-70), pointing out that his appearance on prime time television, at a time when black performers in the media were invariably confined to little more than token characters, is worthy of further academic attention. Indeed, most academic analyses of representations of race and ethnicity focus on the negative depiction of the Other. However, Ahmed argues that the study of characters such as Seretse makes a significant contribution to these debates.

\section{References}

Brunt, R. and Cere, R. (eds.) (2011) Postcolonial Media Culture in Britain, Hampshire: Palgrave Macmillan.

Eagleton, T. (1998) 'Postcolonialism: The case of Ireland', in D. Bennett (ed.) Multicultural States: Rethinking Difference and Identity, London: Routledge, pp. 125134.

Hall, S. (ed.) (1997) Representations: Cultural Representations and Signifying Practices, London: Sage.

Krishna, S. (2009) Globalization and Postcolonialism: Hegemony and Resistance in the Twenty-first Century, Plymouth: Rowman \& Littlefield.

Macdonald, M. (2011) 'Discourses of separation: News and documentary representations of Muslims in Britain', in R. Brunt and R. Cere (eds.) Postcolonial Media Culture in Britain, Basingstoke: Palgrave Macmillan, pp. 127-141.

Pawling, C. (2011) 'Debating contemporary Postcolonial Theory: The limitations of a culturalist approach', in R. Brunt and R. Cere (eds.) Postcolonial Media Culture in Britain, Basingstoke: Palgrave Macmillan, pp. 142-155.

Poole, E. (2002) Reporting Islam: Media Representations of British Muslims, London: IB Tauris.

Poole, E. and Richardson, J. (eds.) (2006) Muslims and the News Media, London: I.B. Tauris.

Said, E.W. (1978) Orientalism, London: Routledge and Kegan Paul. 
Sanz Sabido, R. (2013) Representations of Terrorism in the Israeli-Palestinian Conflict: A Postcolonial Critical Discourse Analysis of the British Press (1948-2009). Unpublished PhD Thesis, De Montfort University.

\section{Biography}

Dr Ruth Sanz Sabido is a Lecturer in Media and Communications at Canterbury Christ Church University, and has previously lectured at De Montfort and Leicester University. She has a PhD in Media Discourse and chairs the MeCCSA Social Movements Network. She was Chair of the MeCCSA Postgraduate Network from 2011-2013. Ruth has written on the Palestinian conflict, the 'war on terror', memories of the Spanish Civil War, social movements and media discourse. She can be contacted at ruth.sanz-sabido@canterbury.ac.uk.

\section{Acknowledgements}

I would like to thank the authors of these papers for contributing their material to this special edition, and for their co-operation and patience throughout this project. I would also like to thank the editors that I have worked with for their support, and particularly Simon Dawes for making this special issue possible. The peer reviewers played a crucial role and offered useful feedback for the authors in a timely fashion. My family provided a supportive environment and constant encouragement, especially in more challenging times. 